Jakub Galuszka

\title{
Adapting to informality: multistory housing driven by a co-productive process and the People's Plans in Metro Manila, Philippines
}

Journal article | Accepted manuscript (Postprint)

This version is available at https://doi.org/10.14279/depositonce-10072

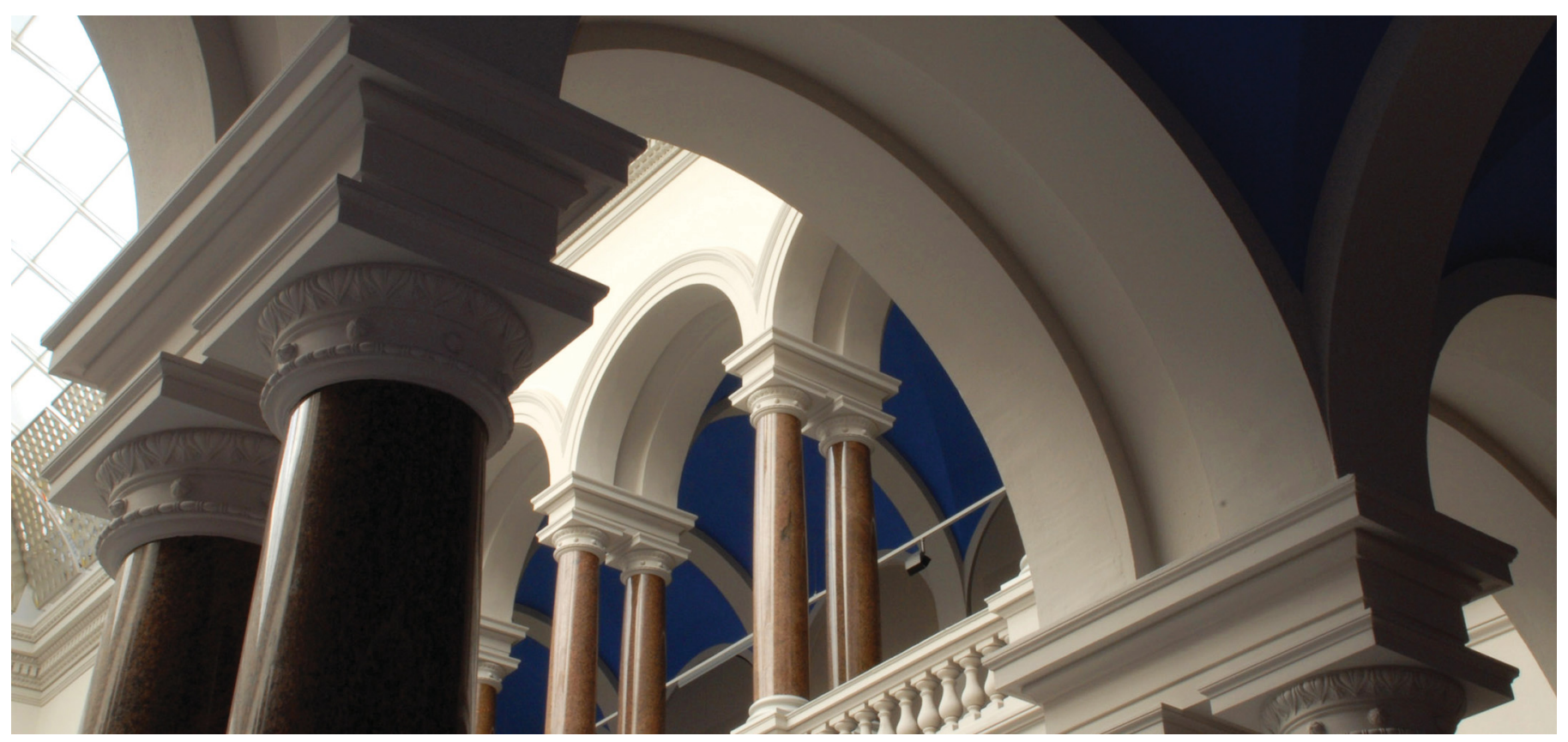

This article has been peer-reviewed, accepted and published in:

Galuszka, J. (2020). Adapting to informality: multistory housing driven by a co-productive process and the People's Plans in Metro Manila, Philippines. International Development Planning Review, 1-29.

https://doi.org/10.3828/idpr.2020.8 
Adapting to informality: multi-storey housing driven by a co-productive process and the People's Plans in Metro Manila, Philippines

Abstract Faced with an ever-increasing demand for land in Metro Manila, as well as with the domination of standardised low-income housing models, the local civil society and the urban poor sector embarked on the development of an alternative shelter approach: in-city multi-storey housing delivered through the People's Plans. The article documents the emergence of the approach, interrogates its main assumptions and takes a closer look at the implementation process through two case studies, in Pasig and San Jose Del Monte. The article analyses the modality as an attempt to create a hybrid approach between formal and informal delivery systems within the built form conventionally associated with the imaginaries of the 'formal' city. The findings underscore the role of co- production in enabling the urban poor sector to leverage their approach, while documenting the need to move beyond a formal-informal dichotomy in both theory and urban development practice.

Keywords Co-production, formal-informal binary, multi-storey housing, People's Plans, Metro Manila, resettlement, public sector, civil society, climate change

\section{Introduction}

With the growing pressure on land and housing in rapidly urbanising Asian cities, multistorey housing has become one of the key alternatives for accommodating the increasing lowincome urban population. Considering the costs as well as complicated construction and management issues, most developments of this type have been facilitated in a top-down manner by public sector agencies. As in similar mass housing schemes across the globe, this has typically led to limited input from the beneficiaries during the planning process and has resulted in issues such as peripheral locations or inappropriate design (Lin, 2018) as well as the dismantling of tight social networks and the spatial formations of informal settlements that enabled a mix of living and working spaces (Hasan et al., 2010). Consequently, although the availability of decent shelter is a key determinant of people's welfare, these types of mass housing projects have reportedly had limited positive socio-economic impacts on their beneficiaries (Buckley et al, 2015; Huchzermayer \& Misselwitz, 2016). In the South-East 
Asia context, which is the focus of this article, co-productive or self-help approaches have been reserved mainly for slum upgrading or site and service interventions, which were heavily promoted by international development agencies from the 1970s onwards (Giles, 2003). Currently, in contexts where civil society is active and land prices are sky-rocketing, multi-storey housing driven by people's organisations emerges as an important, yet underexplored, alternative for the housing delivery system. Apart from its obvious relevance in addressing low-income housing backlog, this approach emerges as an embodiment of the reciprocal relationship between the formal and informal nature of contemporary cities (Dovey, 2012) within a spatial form conventionally labelled a 'formal' type of housing. This article concentrates on the creative process of this approach, which represents an alternative to the conventional logic of informal spatial structures being consolidated and 'incorporated' into the city. It illustrates a solution in which the development of a spatial structure conventionally associated with the imaginaries of a formal city is driven by people rather than exclusively by the public sector. The approach rejects the assumption that the creation of this type of built form requires that the formal process be rigidly followed and that constructive input of communities into housing development can happen solely in the context of incremental upgrading of low-rise settlements. In other words, through the application of People's Plans based on a co-production principle housing development becomes infused with solutions originating from the urban poor sector.

The People's Plan is defined as 'a resettlement option and community development plan formulated by People's Organisations, with or without the support of NGOs, Local Government Units and National Government Agencies' (National Technical Working Group, 2014). The process assumes that urban poor communities can take on a key role in all aspects of multi-storey housing development including: community organisation and profiling; land acquisition; creation of developmental, architectural, engineering, site development, financing plans; co-management of construction works and input into those works as well as creation of community development plan including livelihood and estate management components (Asia Foundation, unknown). The analysis presented in the article documents this process and reviews the ways in which people's solutions attempt to reverse the conventional logic of multi-storey housing development. In theoretical terms the article contributes to the pivotal debate on the positioning of informality in contemporary cities (Roy and AlSayyad, 2004) and the need to transcend 'the othering of informality for the benefit of a more inclusive urban theory contribution' (Acuto et al., 2019). It does so by reflecting on the three spheres conventionally identified in the academic debate as forming the dichotomy 
between formal and informal: spatial categorisation, organisational form and governmental form (McFarlane and Waibel, 2012). The research points out the importance of framing of informality and formality as a practices rather than spatial category (McFarlane, 2012a:105) and illustrates that the formulation of spatial form conventionally seen as formal may be driven by highly hybrid forms of organisation and governance. Simultaneously it reflects on the positioning of co-production as one of the approaches that may be structuring planning practice in the South (Watson, 2014) and providing an opening which allows for the leveraging of solutions developed within the spectrum of informal urbanisation (Galuszka, 2019a).

The article is structured as follows: firstly, approaches incorporating an informal housing process within the formal context are presented and juxtaposed with the top-down multi-storey housing delivery system seen in the South-East Asian context. This is followed by a debate on co-production as an approach which enables the integration of different planning perspectives in the housing development process. Sections 4 and 5 introduce the specifics of housing in Metro Manila and a recent governance shift while briefly discussing the openings it has provided for the mainstreaming of people's solutions. Section 6 examines the assumptions of the People's Plans through the review of main phases of the housing development process, the role different stakeholders take in it and the ways formal and informal approaches interact with each other. In the final part of the article, the ability to execute the principles of People's Plans in practice is illustrated through two case studies demonstrating the implementation of people-led multi-storey housing in Metro Manila, Philippines. This is followed by a debate on the relevance of the approach in crossing the formal-informal binary and the challenges it encounters at project level.

The analysis is conducted in the context of the Oplan LIKAS programme which was realised in the Philippines between 2011 and 2016 with the aim of resettling around 120,000 informal settler families from flood-prone danger zones in Metro Manila. Due to the big impact of the local urban poor sector and civil society on the design of the programme, one of the multi-storey housing modalities integrated the approach of co-production through People's Plans created by the community organisations involved. The debate in this article is based on fieldwork data collected between November 2017 and March 2018 through 37 interviews with civil society and public sector actors engaged in the development and implementation of the Oplan LIKAS housing modalities as well as the analysis of secondary data sourced from key shelter agencies, the Department of Interior and Local Government (DILG) and civil society. This part of the research contributes to the discussion of the 
governance context and the assumptions of the People's Plans as a hybrid formal-informal housing process. The analysis of two case studies testing these assumptions is based on 8 interviews ( 3 in a group setting) with community leaders, involved NGO intermediaries, public sector agencies in charge of the housing modalities under discussion as well as transect walks on the sites and an analysis of secondary data related to the relevant housing. Although the case studies are not representative of all multi-storey projects realised within Oplan LIKAS, they allow for a demonstration of the ways in which people's approaches were infused into the formal process, and help identify the challenges and successes encountered in the process.

\section{Low-income housing in Asian and South-East Asian contexts: 'adapting informality'}

Along with the rapid population growth in Asian cities, the issue of a housing backlog has been experienced by the majority of states on the continent, with $61 \%$ of its population living in informal settlements and slum-like conditions (Bredenoord et. al, 2014). With limited resources and encouraged by major international agencies such as the World Bank and the UN (Arku, 2006), many low-income housing solutions from the 1970s in South and SouthEast Asia were framed in line with the enabling approach (Giles, 2003) aiming at the development of housing markets. In parallel, aided self-help strategies, which concentrated on the bottom up activities in housing development, gained wide recognition. This orientation stemmed from the revolutionary works of Turner and Fitcher (1972), who recognised that people are a driving force in the creation of contemporary cities and that their approaches may serve as a backbone for housing programmes. In the context of informal settlements, this meant involving communities and the private sector in the process of developing housing and promoting solutions such as aided self-help, slum upgrading or incremental development. In other words in those cases governments tactically accepted elements of informal development, while imposing their hierarchies and rules of implementation (Pieterse, 2013). Among the most successful programmes were the Million Houses Program in Sri Lanka (1983-1994) (Joshi \& Khan, 2010), the Kampung Improvement Programme in Indonesia (1969-1993) (Salas, 1992). During the 1970s and 1980s, these approaches spread through the continent and, when coupled with stable economic growth, supported many informal dwellers (Yap, 2016), either with decent housing or access to services.

Turner's holistic approach, however, did not translate into a general recognition of informal urbanisation as a natural component of contemporary cities. A large number of slum 
upgrading projects were motivated by a neo-liberal paradigm that shifted responsibility for development from the state to the people (Burgess, 1978). Much of the developmental and technical support delivered by international agencies was, in fact, tied to compulsory reforms, which incentivised states to retreat from service delivery (Pieterse, 2013). Similarly, cooption of the inclusive mechanism plagued many projects (Lemanski, 2017) which were sometimes used as tokens to replace wider pro-poor reforms (Karaos, 2006). Consequently, while many state-initiated slum upgrading projects recognised a formal-informal sector hybridity in terms of spatial dimensions, in some cases they also did the opposite in terms of applied implementation logic and organisational choices. This is debatably the case in the application of De Soto inspired tenure solution, which pushes for individual ownership as a superior model for informal settlements and has been eagerly adopted across different contexts as a policy of choice, ignoring a range of different tenure models practised by poor communities and often better suited to their needs (Payne et. al, 2009). Similarly, some upgrading projects delivering formal housing have enhanced the quality of life of the beneficiaries but at the same time have also led to the dismantling of the previously strong informal organisation of the community and to the gradual erosion of social cohesion (Brown-Luthango, 2016).

\section{Multi-storey housing in the region: delivering 'formal' city}

Over time, the use of in-situ participatory upgrading approaches declined in many contexts, particularly in central locations of big metropolises. This was due to rising land values and increasing pressure from the growing middle class (Yap, 2016), as well as to ideological currents pushing the vision of a 'global metropolis' (Garrido, 2013) free of spatial structures resembling informal settlements (including those already upgraded).

Consequently, in recent years some states focused more resources and attention on massive top-down relocation schemes like Housing for All by 2022 in India, which facilitated development of apartment blocks located on urban peripheries (Huchzermayer and Misselwitz, 2016). In South-East Asian countries similar approach typically occurred concurrently with the self-help approaches of the 1980s. Examples of top-down mass housing can be found in Singapore and Malaysia (Agus, 2002) and such programmes have also been developed in Thailand (Baan Ua-Arthorn programme) (Yap and Wandeler, 2010) and in Indonesia ('Rumah susun' multi-storey housing) (Warouw et al., 2010). Although the topdown approach has been considered successful in states with ample resources such as 
Singapore, in many other contexts multi-storey housing has experienced a variety of problems.

While many of these problems arose from practical issues such as land policies and technical errors, I argue here that many were the consequence of the top-down manner in which most multi-storey housing is developed. They stem from the insistence that this kind of spatial form must fit in with the 'formal city' vision, in spite of the fact that an adaptation of people's solutions could be a remedy for some of the issues. The clash between formal and informal resonates strongly when juxtaposing the morphology of top-down multi-storey housing with the spatial knowledge of informal settlers relocated to those contexts. Disorderly informal settlements were to be replaced with standardised structures, even if these structures jeopardised the livelihoods of the beneficiaries (Hasan et al., 2010). The peripheral locations, dictated by low land prices and municipal land use planning logic, led to the loss of informal sources of income for the settlers and, in effect, resulted in working members of some families abandoning the properties. Finally, the high cost of the structures, including additional expenses created by the appointment of external maintenance and management corporations, made the low-cost condominiums unaffordable and an easy target for speculation by higher income groups (as has been documented in the case of the Baan UaArthorn programme). Likewise, multi-storey housing can be motivated by political gain and tainted by too-close relations between the real estate sector and the decision makers (Yap and Wandeler, 2010).

In spite of the strong formal machinery and imaginaries of an orderly city, these types of structures can, paradoxically and against the intentions of the housing delivery system, become hybrids of what is perceived as formal and informal. In such cases the occupants appropriate spaces according to their needs, often at the cost of re-stigmatising their homes as vertical slums, with the risk of further relocation (figure 1). The following parts of this article discuss the potential for including the people's approaches at an earlier stage in the housing development process. 


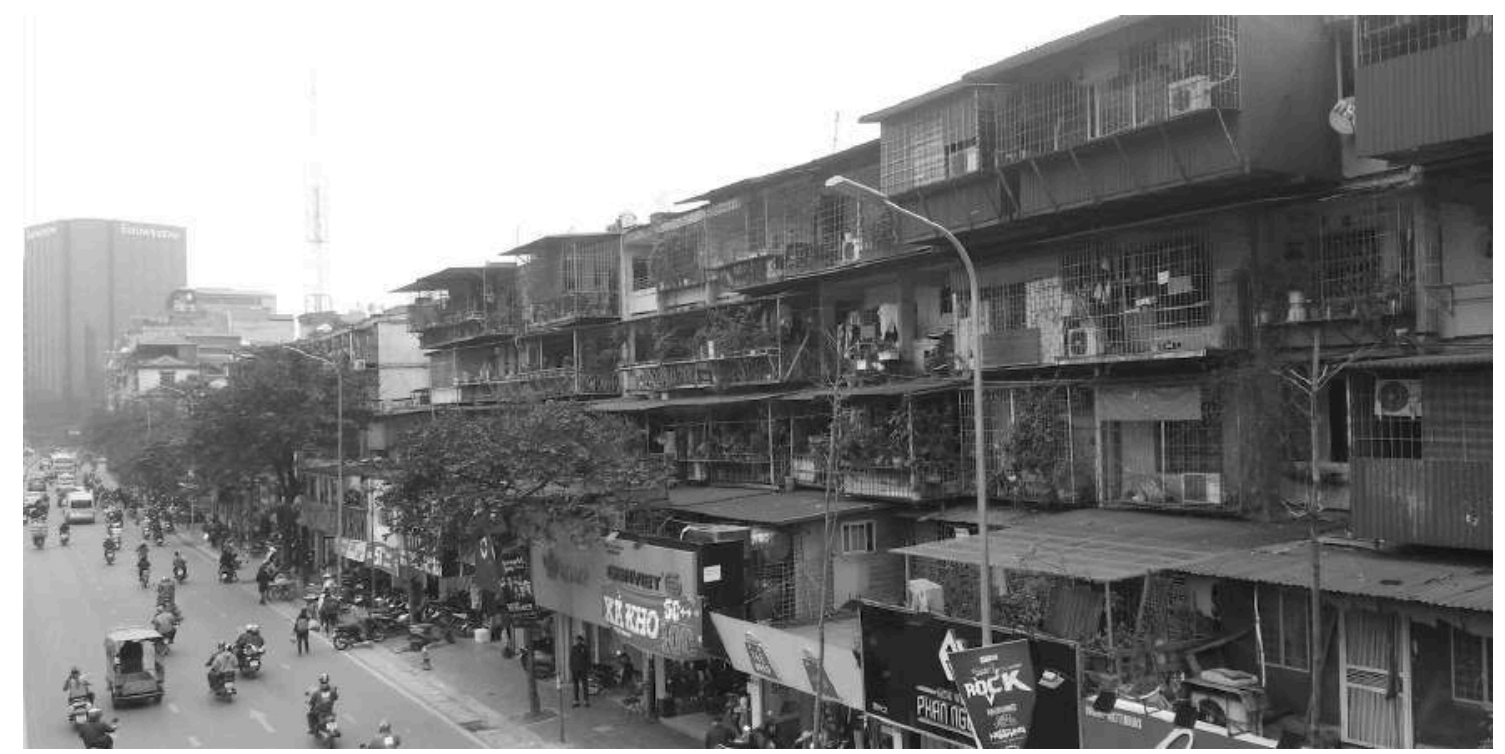

Figure 1. Block of flats with extensions in Hanoi city, Vietnam

\section{Co-production: adapting to informality}

Since the 1970s co-production has been discussed as a promising approach to optimising the delivery of goods or services through inputs provided by a variety of stakeholders (Ostrom, 1996). Typically, these included representatives of the public sector on the one hand and citizens or representatives of civil society on the other. Overall, the benefits of the approach were discussed in terms of decreased costs for the public sector and better outputs for the people (Albrechts, 2012). In the context of the global South, an important aspect of the empowerment of marginalised groups was also raised: groups such as the associations of urban poor or people's organisations utilised this approach in order to be recognised as valid partners for the public sector, capable of providing real input into service delivery activities. Ultimately, this meant a 'process that opens space for poor communities to work with their local governments and other public and private stakeholders to deliver various development goods' (Boonyabancha and Kerr, 2018: 444). More broadly, co-production was seen in the South as reflecting urban poor approaches, particularly when initiated by the urban poor groups themselves (Watson, 2014).

On the ground, the practice of co-production differed depending on the context in which it emerged, the political environment and the level of mobilisation of the civil society (Mitlin, 2018). Bovaird (2007) divided citizens' groups into three categories: those involved solely in the planning of a specific service, those involved solely in its delivery, and those involved in both. Within the European context, the first of these was tested in the case of 
cooperative housing, with a group of citizens playing a major role in the planning of multistorey housing. In the Southern context, the co-production of housing and self-help approaches were most commonly applied through the engagement of the people in the construction process. Sweat equity solutions were often utilised by the public sector to facilitate housing delivery at a low cost, while providing employment opportunities for community members. This practice was common on incremental projects (Greene and Rojas, 2008), with co-productive solutions being applied typically to in situ upgrading and the development of low-rise settlements. Some recognition of the co-productive process within multi-storey housing is visible in Latin America, for instance in the case of cooperative housing solutions in Uruguay. This includes the FUCVAM federation representing a social movement which emerged within the context of self-help construction and, with time, moved to the development of multi-storey housing. Through close cooperation with professionals and the public sector as well as an institutionalised housing development process, it achieved significant low-income housing delivery, summing up to approximately 30,000 households (Barenstein and Pfister, 2019).

In the dominant model of in-situ upgrading of informal settlements, the community groups could provide input into the design of the neighbourhood and negotiate particularities of a project, but control over the development process was achieved mainly thanks to their direct involvement in the construction of the housing or the infrastructure. The involvement of both the urban poor sector and the public sector allowed aided self-help to be seen as an adaptive format enabling planning with informality. In some interpretations, this translates to the creation of 'positive hybridity', where the informal sector develops practices that correlate with formal planning (Song, 2016). However, rather than implying an adaptation to the formats of government, those practices are fluid and include both compliance and resistance (Roy, 2009). Co-production, in contrast to participatory planning, challenges the formal logic of the process by working outside existing regulatory frameworks and hierarchies, as well as by involving the urban poor in both planning and construction. However, similarly to participatory planning approaches, the application of co-production may run risks in terms of exploitation of community relationships and networks (Beall, 2001). For instance, the public sector may be solely interested to use those relationships to benefit from community effectiveness in service delivery (Mitlin and Bartlett, 2018). Avoiding these kinds of risks depends, to a large degree, on the ability of community groups to maintain a degree of independence from their counterparts in public sector (Galuszka, 2019a). This is typically facilitated by social movement initiated co-production. Its elements, 
such as incorporation of conflict-based strategies rather than collaboration only or principles of collective action, are ensuring a more equal power balance between communities and public sector (Watson, 2014; Bradlow, 2015). Overall, co-production, rather than only supporting policies which utilise informal solutions within housing formalisation, is also directed at creating laws which recognise people's approaches, hence truly adapting regulatory frameworks to aspects of informal urbanisation (Galuszka 2019a) (as debated, for example, in the context of the Baan Mankong programme) (Boonyabancha \& Kerr, 2018). However a strong focus on the mainstreaming of existing on-the-ground solutions through a showing by doing strategy and slow bottom-up work has primarily meant operating within spatial forms widely associated with the imaginaries of informal cities. As a result, opportunities to apply a true co-productive process within the multi-storey housing context have been scarce, this being judged an inappropriate built form for the needs of informal settlers by the urban poor themselves (Karaos, 2006). Therefore, what is discussed in the literature as social-movement initiated co-production (Watson, 2014) rarely incorporates spatial forms associated with the formal city. Efforts to transcend this approaches have been made in Metro Manila over the past 10 years ${ }^{1}$.

\section{Housing in Metro Manila}

Contemporary Metro Manila is one of the world's largest metropolises, with approximately 13 million people of whom between 1.3 and 3 million are estimated to live in informal settlements (World Bank, 2016; 2017). The People's Plan approach stems from several decades of efforts of the urban poor and civil society to leverage people's solutions into the official planning system. While initially the expansion of informal settlements had unorganised characteristics, with time strong social movements emerged in Metro Manila. Typically, those groups operated within informal settlements but the growing pressure on land from private sector (Garrido, 2013, Kleibert, 2018) pushed many of the existing coalitions to recognise that the engagement into the development of mid-rise buildings was the only viable option for avoiding relocation to the urban periphery. This approach became particularly relevant also wherever in-situ upgrading of settlements was not possible, as in the two discussed case studies of the APAOAM-F and ALPAS. In those contexts Local

\footnotetext{
${ }^{1}$ The term co-production is used relatively rarely in the Philippines, even within the programmes representing features of the approach. Those are more commonly labelled as bottom-up process or a form of participatory governance.
} 
Government Units were obliged by the Supreme Court mandamus from 2008 to evacuate the aforementioned communities from waterways in which they resided because of flooding and environmental hazards.

In fact, the issue of relocation was an ever-lasting problem in Metro Manila, which fuelled the emergence of organised urban poor groups from the middle of $20^{\text {th }}$ century onwards. Initially, in the early post-colonial period, the growing population of the metropolis was accommodated through the development of new satellite settlements and mass-produced bungalows (Morley, 2018). However, with the rise to power of Ferdinand Marcos in 1965, informal settlers were increasingly pushed out of their homes (Shatkin, 2002).

The 1970s were the start of a centralised public housing policy period (Ballesteros, 2002). In 1975 the National Housing Authority (NHA) was established to 'provide and maintain adequate housing for the greatest possible number of people' (Presidential Decree, 1975: 2). The agency became, and still is today, the main institution in the country responsible for facilitating the resettlement of informal settlers. Its main task and practice was to construct vast, sprawling low-rise resettlement sites on the outskirts of the metropolis. During the same period the first low-income multi-storey housing project was tested via an Imelda Marcos-'led' initiative, the BLISS programme, though a mere 2500 units were actually produced. Due to alleged corruption and the use of expensive design solutions and materials, the project turned out to be unaffordable (Shatkin, 2004). Next to those top-down solutions some alternative shelter provision approaches were tested, including site and service projects, core housing and slum improvement (Ballesteros, 2002). A landmark alternative approach was tested with the World Bank-supported Tondo Foreshore Urban Development Programme. Although the programme promoted self-help solutions, its implementation happened in a repressive environment which seriously limited the extent of the urban poor's participation (Storey, 1998). A broader change in urban development legislation happened after the People's Power Revolution in 1986. Enabling laws like the Local Government Code of 1991 and the Urban Development and Housing Act of 1992 (UDHA) marked the beginning of the devolution/privatisation period in the local housing market (Ballesteros, 2002). This legislation opened the way to wider involvement of community-based organisations and NGOs in developmental projects as well as, at least in theory, guaranteed protection from forced evictions.

However, in spite of supportive legislation, a flourishing civil society and the formation of urban poor groups (Yu \& Karaos, 2004; Karaos \& Porio, 2015), the low-income housing provision system did not change in an substantial way. Rather than enabling the 
inclusion of informality in the structures of the city the public housing programmes facilitated its eradication, with massive relocation schemes dominating over progressive in-situ upgrading approaches like the Community Mortgage Program (Galuszka, 2014). This paradox was linked to the positioning of the urban poor and civil society actors as leaders of the upgrading process while subjecting them to the patronage of powerful figures and intrabureaucratic power struggles (Porio, 2012; Shatkin, 2016; Hutchison 2007). Although some groups were successful in reaching their locally-based goals like getting access to public land, the wider movement advocating for broader changes in land policies was systematically dissolved by powerful actors in the country (Karaos, 2006). Prior to Oplan LIKAS, vertical densification through construction of multi-storey housing was rarely seen as part of the solution for the urban poor, and even more rarely was put into practice with any real input from the urban poor sector. Some examples of this type of housing was developed on the basis of a variety of usufruct arrangements and include projects driven by the local government units and NHA or charitable organisations like Habitat for Humanity or Gawad Kalinga (Karaos et. al, 2011; Galuszka, 2014).

\section{Governance openings for pro-poor solutions: 50 billion fund and Oplan LIKAS formation}

The shift towards a multi-storey building strategy was a result of the clamouring of a big segment of the urban poor movement and the consensus that it was essential for the informal settlers to avoid off-city relocations. Even though the urban poor traditionally contested midand high-rise developments (see Karaos, 2006), the scarcity of land in the metropolis led to a larger acceptance of this type of housing. A key driver in leveraging the approach was the organisation of urban poor groups into the Urban Poor Alliance in 2005, which eventually led to the establishment of the 10 Points Covenant between the civil society and presidential candidate Benigno Aquino III (Porio and Karaos, 2015). The document acknowledged the main demands of the urban poor sector on a policy level and supported the development of the 50 billion pesos fund (ca. US\$1.15 billion) and the Oplan LIKAS programme (20102016). The programme envisaged the relocation of around 120,000 informal settler families (ISFs) from danger zones in Metro Manila into affordable housing. Initial work on the programme positioned the civil society and urban poor actors as its main co-producers, thus enabling them to have a real impact on governance matters. This was reinforced by the employment of civil society representatives in two out of three main public sector agencies 
dealing with the Oplan LIKAS. Although heavily contested within the sphere of formal governance (Galuszka, 2019b) and eventually utilised by power holders to accelerate confrontation-free relocation of informal setters from danger zones (Alvarez, 2019), the new context provided some openings for the adaptation of housing approaches to the agenda of the urban poor. These openings were realised through the establishment of multi-storey housing modalities within local shelter agencies, with two programmes being truly informed by urban-poor preferred solutions (table 1). This involved the incorporation of two main advocacy points of the urban poor sector; the People's Plan and in-city multi-storey housing. In principle vertical development meant that more informal settlers could be accommodated in the vicinity of their original settlements and avoid city-edge relocation. At the same time, there was more space for the development of public facilities and amenities (Turok, 2016). The People's Plans retained control by communities over the key points of housing estate development.

Ultimately, the whole process meant that different aspects of estate development would be shared between a community association (in the form of a registered homeowners association or cooperative), a shelter/government agency or LGU providing financial and organisational support, and civil society mobilisers supporting the organisation of the community. It also included a private developer who was mainly responsible for construction.

Table 1. Summary of agencies and projects involved in the development of multi-storey housing.

\begin{tabular}{|c|c|c|c|c|c|c|}
\hline Agency & Agency's profile & $\begin{array}{l}\text { Main Multi-storey } \\
\text { housing modality }\end{array}$ & Start & $\begin{array}{l}\text { Land } \\
\text { modality }\end{array}$ & $\begin{array}{l}\text { Delivered units } \\
\text { (SHFC/DILG - by the } \\
\text { end of 2017, } \\
\text { NHA- by the end of } \\
\text { 2016) }\end{array}$ & $\begin{array}{l}\text { Store } \\
\text { ys }\end{array}$ \\
\hline $\begin{array}{l}\text { National } \\
\text { Housing } \\
\text { Authority }\end{array}$ & $\begin{array}{l}\text { Largely top-down } \\
\text { approach and } \\
\text { delivery of far off- } \\
\text { city resettlement } \\
\text { sites; contested by } \\
\text { the civil society } \\
\text { organisations. }\end{array}$ & $\begin{array}{l}\text { In-city resettlement } \\
\text { housing } \\
\text { programme: } \\
\text {-Design and Build } \\
\text { modality } \\
\text {-Community } \\
\text { Initiative Approach } \\
\text { [CIA). }\end{array}$ & 2012 & $\begin{array}{l}\text { Usufruct, } \\
\text { Land provided } \\
\text { by NHA or } \\
\text { LGU, CIA } \\
\text { envisaged on } \\
\text { private land. }\end{array}$ & $\begin{array}{l}36 \text { projects: } \\
-8644 \text { completed } \\
\text { units } \\
-4876 \text { under } \\
\text { construction } \\
-3228 \text { planned }\end{array}$ & $2-5$ \\
\hline $\begin{array}{l}\text { Social } \\
\text { Finance } \\
\text { Housing } \\
\text { Corporation }\end{array}$ & $\begin{array}{l}\text { Experienced in the } \\
\text { tenure-oriented } \\
\text { Community } \\
\text { Mortgage } \\
\text { Programme. Linked } \\
\text { to the civil society } \\
\text { during Oplan LIKAS } \\
\text { implementation } \\
\text { process and } \\
\text { supportive towards } \\
\text { its approach. }\end{array}$ & $\begin{array}{l}\text { High Density } \\
\text { Housing } \\
\text { Programme (HDHP) } \\
\text {-HDH based on } \\
\text { People's Plans } \\
\text {-HDH refinancing } \\
\text { scheme. }\end{array}$ & 2013 & $\begin{array}{l}\text { Usufruct, } \\
\text { private land } \\
\text { identified by } \\
\text { the community. }\end{array}$ & $\begin{array}{l}27 \text { projects: } \\
-4935 \text { completed } \\
-9384 \text { under } \\
\text { construction } \\
-5750 \text { planned }\end{array}$ & $2-5$ \\
\hline $\begin{array}{l}\text { Department } \\
\text { of Interior } \\
\text { and Local } \\
\text { Government } \\
\text { (delivered } \\
\text { via.SHFC or } \\
\text { LGUs) }\end{array}$ & $\begin{array}{l}\text { Linked to civil } \\
\text { society during Oplan } \\
\text { LIKAS } \\
\text { implementation and } \\
\text { supportive towards } \\
\text { its approach. } \\
\text { Delivering money } \\
\text { for in-city housing } \\
\text { via the Social } \\
\text { Finance Housing } \\
\text { Corporation or LGUS }\end{array}$ & $\begin{array}{l}\text { Micro-Medium-Rise } \\
\text { Buildings (MMRB) }\end{array}$ & 2015 & $\begin{array}{l}\text { Usufruct, } \\
\text { private land } \\
\text { identified by } \\
\text { the community. }\end{array}$ & $\begin{array}{l}9 \text { projects: } \\
-434 \text { completed } \\
-34 \text { under } \\
\text { construction } \\
-1780 \text { planned }\end{array}$ & $1-5$ \\
\hline
\end{tabular}




\section{Co-production in context - adapting to an 'informal' organisational model within a 'formal' built form}

While the shift towards multi-storey housing was motivated by the desire to avoid off-city relocation, the People's Plan is supposed to enable the inclusion of people's solutions in the formal housing development process. Its processes stem form broader governance shift and assumed that the communities can take a central role in housing planning, organising, development and maintenance. More precisely, the process includes the direct role of communities in:

- community organisation and profiling,

- search and acquisition of land,

- financial planning,

- input into preparation of site development plan and housing design solutions,

- management planning,

- preparation of a community development plan, including property management and a livelihood plan (Patiño, 2016; Asia Foundation, unknown).

Due to their focus on multi-storey housing and in-city relocations, the People's Plan is an instrument for empowering people to take on a lead in a process which is conventionally seen as a field of expertise of professionals and typically facilitated in top-down manner by public sector. Although the public sector perceived this solution mainly as an innovative housing finance scheme or as a bottom-up housing process, the approach emerges as a form of institutionalised co-production. This is encapsulated in the contribution that both sectors do in all of the phases of the process (although this contribution may be varying based on different skills and capacities of the involved groups). In contrast to well-known incremental relocation projects like Khuda Ki Basti (Hasan, 1990) the process meant infusing formal housing development processes with informal solutions at the planning and organisational stages rather than at the time of construction. It also enabled communities rather than the public sector to assume the role of initiators of specific projects. In this context the application of a co-productive approach responded both to the practical need to address the shortcomings of the state with regard to the delivery of its statutory functions (Josie and Moore, 2004) and to the people's demands for the power to shape the housing delivery process (Mitlin, 2008). Simultaneously, the approach opens up opportunities of integration of formal and informal solutions in one scheme (Shand, 2018) and, when successful, supporting 
emergence of positive hybridity between the two sectors (Song, 2016).

Community organisation and profiling are the first elements of People's Plans. In essence the role of resettling authority is taken over by the communities themselves, usually with the help of an associated NGO. The process involves defining the people who are to take part in relocation, deciding on the process and, typically, mobilising community resources through saving schemes or other mechanisms (Ballesteros et.al, 2017). On formal ground it requires the group to register as a Homeowners Association or a housing cooperative.

Similar to the process of enumeration, which is incorporated in many co-productive engagements, the profiling of potential beneficiaries was a first step towards knowledge creation which translates to more equal power relations between community groups and the state (Patel et. al, 2012). According to one civil society activist, the process can have profound implications and strengthen the positioning of concerned groups within the local governance spectrum:

'In their own relocation sites they ((public sector)) can control people, who will be HOA (homeowners associations) officer, who should be evicted (...). If people win their People's Plan because some of the opposition from the political bloc will approach ((them)) (...) so it can be, for example, 900 families times 3 voters, gives 2700 (...) they can win Barangay ${ }^{2}$ captain who can be influential to some Councillor' (civil society/ public sector, 03.02.2018) ${ }^{3}$. The organisation and selection of beneficiaries therefore becomes more a matter of internal community dynamics and helps to build capital for the formation of ad hoc political coalitions involved in negotiations with the bureaucratic apparatus of the state. This approach requires ample time for organisational activities and runs the risk of non-transparent and exclusive internal power dynamics (Rigon, 2017) but aims to steer collective action and prevent co-option.

The second component of the process is the search for and acquisition of land, which addresses the challenge of accessing land in Metro Manila. Previous programmes like Community Mortgage Program recognised the centrality of the issue and provided opportunities for communities to buy the land they were informally occupying. However bearing in mind the numbers of informal settlers and growing land prices dictated by the visions of a formal city encapsulated within the phenomena of enclave urbanism (Kleibert, 2018) a new approach was required within the relocation context. The application of a community-based land search system is linked to the passivity of the Local Government

\footnotetext{
2 The smallest administrative unit in the Philippines.

${ }^{3}$ The interviews are referred to based on the sector represented by the interviewee.
} 
Units in their formulation of Comprehensive Land Use Plans which were supposed to delimit areas intended for the development of social housing. Considering that in 2017 only 5 out of 16 cities and one municipality in Metro Manila had their plans updated (World Bank, 2017) the independent search was envisioned as a remedy for the land access issue. The approach involves a physical search for land (in most cases private land) which means: "we (the community) go around, we go around, then we see a vacant land, then we go to the local government and ask the city mapping, we see owner (of) that parcel' (community-based organisation, 10-03-2018). This is followed by negotiations with the owner, and in the event of a successful resolution, the preparation of a contract of sale all of which resonate true mix of formal and informal process.

The next part of the process involves the creation of a financial plan, preparation of a site development plan, and architectural and engineering design. These elements, in particular the financial plan, depend on the programme modality to which the community groups will apply (see table 1). On the one hand the approach incorporates solutions often practised within the informal sector, such as saving schemes or microfinance mechanism (McFarlane, 2012b). On the other hand it requires adaptation to the cumbersome (Ballesteros et al. 2017) formal process. The degree of support given depends largely on the positioning of the agency administering the loan vis-à-vis the urban poor communities. The communities are put in charge of managing the main components of the process, including the selection of a developer, the debate on the site development plan, its design and the running of workshops to consider the needs of the community.

The project management plan 'details the daily, weekly, and monthly targets of the construction of the new resettlements site' (the Asia Foundation, unknown: 8). This means taking on a supervisory role: carrying out checks on the quality of the delivered site and on the progress of the works. Importantly, as in incremental upgrading schemes the construction process is intended to create employment opportunities (Greene and Rojas, 2008) for the community, through the employment by the developer in charge of the construction works.

Lastly, the communities are supposed to create a community development plan which includes basic services/livelihood plans and an estate management plan. The combination of design input and a livelihood plan is supposed to enable the creation of spaces for livelihood creation within the buildings and the site, responding to criticisms of multi-storey estates as ill-adapted to the needs of informal economies (Hasan, et al. 2010). The crucial aspect of estate management is supposed to be designed by the community after a thorough capacitation process (The Asia Foundation, unknown). The assumption is that the people can 
manage and maintain the estate by themselves instead of paying an external management company. This is positioned as one of the critical aspects of the sustainability of the approach considering that the maintenance issues experienced in low-income multi-storey housing around the world are one of their main drawbacks.

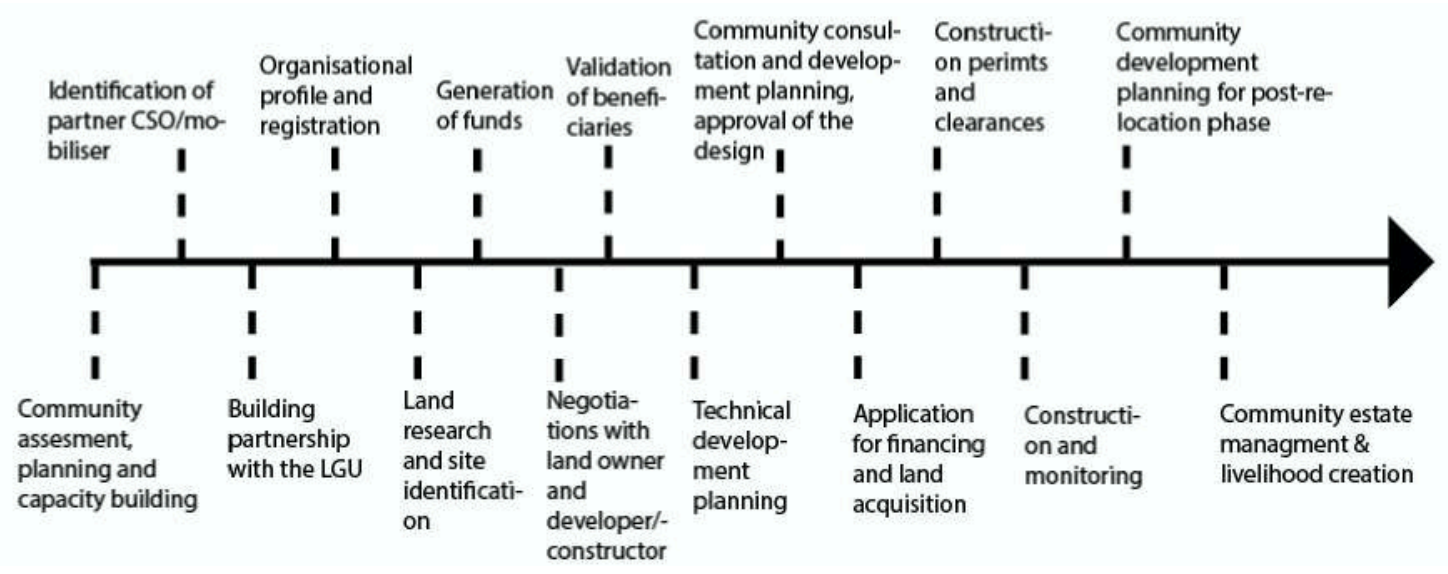

Figure 2. Components of People's Plan - simplified model.

\section{The People's Planning: a closer look}

The two case studies presented test the approach through the review of the role of the concerned communities in the housing development process as well as the analysis of the process in terms of integration of solutions that stem from formal and informal sectors. This review is conducted in relation to all of the key components envisaged as a part of the People's Plan and described in the proceeding section. The selection of case studies is based on the recommendations of civil society and public sector actors involved in the implementation of the Oplan LIKAS programme, against criteria including: the stage of the project, its institutional setting and perceived integration of the People's Plan approach. As such, two projects under different institutional arrangements are reviewed, one involving the National Housing Authority, the second the Social Finance Housing Corporation.

\section{Manggahan floodway low-rise buildings: a co-productive process in a conflict setting}

The Manggahan Floodway was constructed in 1986 with the intention of easing flooding in Metro Manila. Since completion its banks have been gradually utilised by people to build 
informal settlements. The land around the floodway was eventually proclaimed in 1995 and 2006, which meant its ownership was delivered to the National Housing Authority with the intention to use it as a housing site for informal settlers. However, due to the writ of mandamus issued by the Supreme Court of the Philippines, which ordered local government units to clean three-metre-wide areas along the main waterways in Metro Manila, the settlers were again under threat of eviction. The situation was aggravated in 2009 when typhoon Ondoy devastated the metropolis. Much of the land along the Manggahan Floodway was flooded and the informal settlers living in the area were blamed for the destruction that occurred in other parts of the metropolis because of blockage of the floodway by their shacks. In response to the crisis the APOAMF federation (Alliance of People's Organisations Along Manggahan Floodway), integrating 11 local organisations and numbering 2867 registered members, was established in 2010 with the help of a local NGO, the Community Organisers Multiversity. The organisation enabled local leaders to resist relocation and push for their own housing project. In spite of efforts to develop an in-situ upgrading scheme, parts of the settlements were evacuated in 2011. At the same time the Oplan LIKAS programme was being established. According to the programme's initial discussions, a large amount of money was to be devoted to in-city housing developed according to the People's Plans. Following the framework of the scheme, the community positioned itself to receive the funding and initiated a land search which led to the identification of a nearby two-hectare lot, utilised as a motor pool (figure 4). This lot had previously been part of a proclamation site, owned by the public sector and administered by the National Housing Authority. The APOAMF embarked on this opportunity while facing the initial resistance of the public sector, which wanted to devote the site to other purposes. Between 2012 and 2014 (coinciding with the Philippine General Election in 2013) the process involved the informal lobbying of the local politicians and public sector representatives by APOAMF (considered by community leaders as crucial in moving the project forward) as well as the selection of beneficiaries, preparation of competing designs and work on occupancy regulations (table 2). 


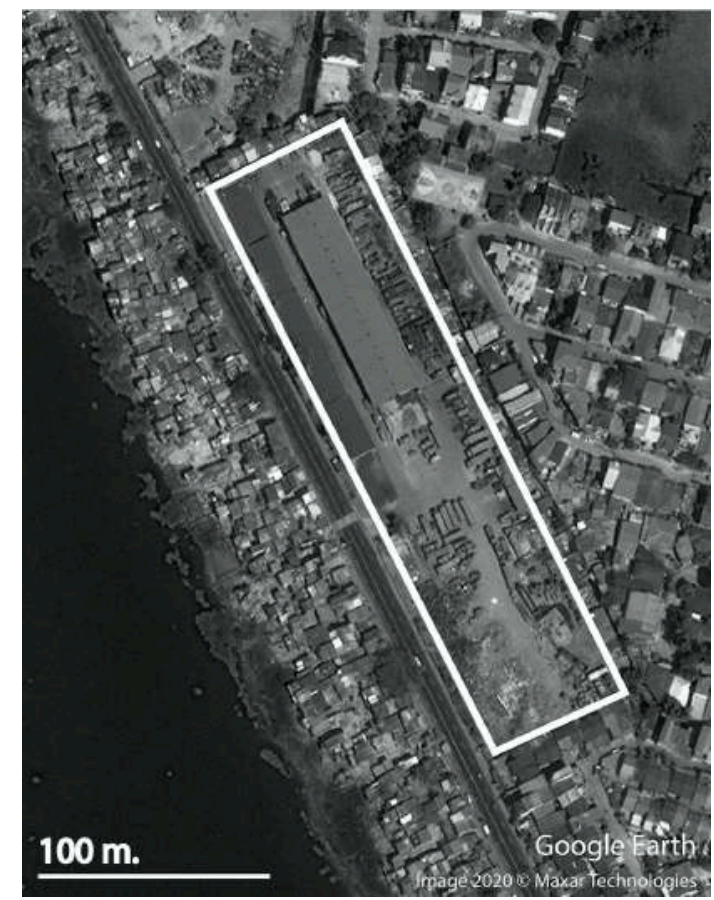

Figure 3. Project site February, 2010, Source: Google Earth

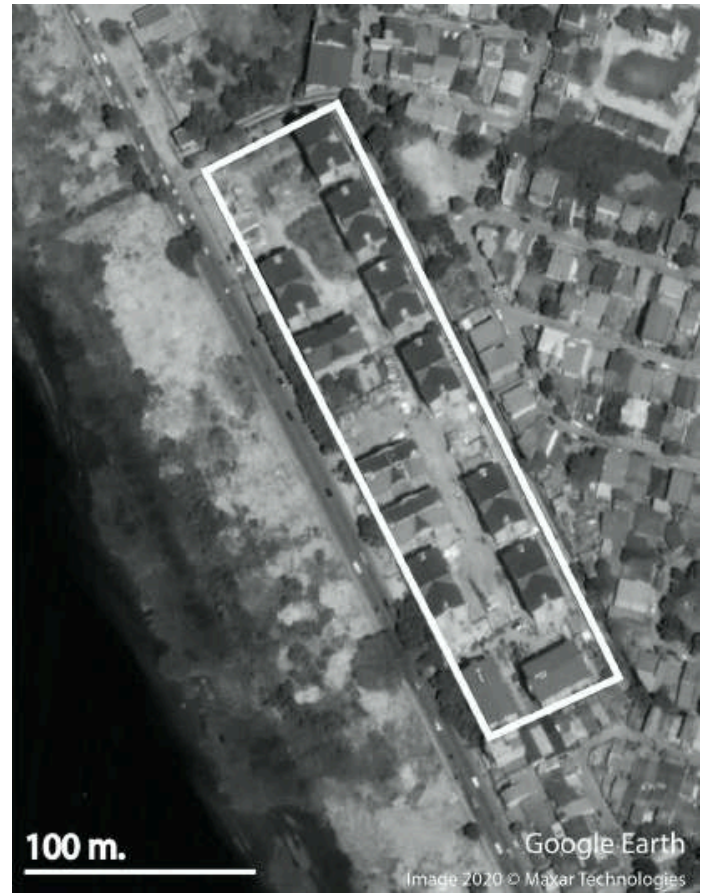

Figure 4. Project site March, 2018, Source: Google Earth

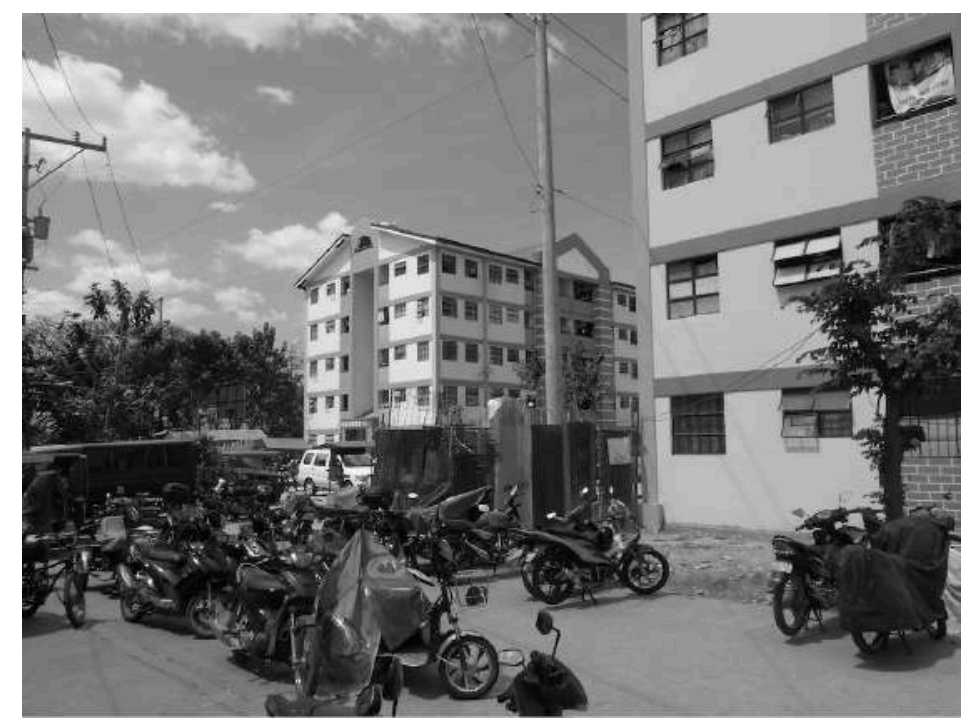

Figure 5. Multi-storey housing developed within the project, source: author

During the process the project was scaled down, resulting in the resettlement of some of the APOAMF members in off-city sites. In addition, the slow construction process meant that, in 2017, some community members who had been forced to vacate their informal settlements had to move into buildings without electricity or water. At the same time the APOAMF was faced with increasing risks of squatting in the vacant buildings by the Kadamay group, which used occupation tactics rather than cooperation with the government. By 2018 only six buildings were completed. Of seven uncompleted buildings, five were at an advanced stage 
but they were suspended due to construction issues with the sub-contractor imposed by the public sector and responsible for the third phase of the project. The final units delivered were up to $24 \mathrm{~m}^{2}$ in size with individual bathrooms. Overall, from a perspective of civil society groups supporting the process, the project was considered a successful application of the People's Plan utilised as a negotiation tool for the construction of housing which would otherwise have been contested by the public sector and could not have happened at the site selected by the community. In many other locations the process of in-city relocation was hampered by the pressure of public sector and 'the people who are along the estero ${ }^{4}$ opted to go to off-site relocation site because (...) they were pressured. Because People's Planning (...) works for those who can have really the patience, (...) in Pasig, APOAM, Alliance of People's Organisations in Pasig it is something like that' (civil society, 08-12-2017). While a part of the public sector shared this opinion, the National Housing Authority disagreed that the project was driven by the People's Plan.

Table 2. Elements of the co-productive process in projects steered by the APOAMF and the ALPAS.

\begin{tabular}{|c|c|c|c|c|c|c|}
\hline Project & $\begin{array}{l}\text { Community and } \\
\text { organisation } \\
\text { profile }\end{array}$ & $\begin{array}{l}\text { Land } \\
\text { acquisition } \\
\text { and } \\
\text { development } \\
\text { plan }\end{array}$ & $\begin{array}{l}\text { Selection of the } \\
\text { developer }\end{array}$ & $\begin{array}{l}\text { Site development } \\
\text { plan and } \\
\text { architectural design }\end{array}$ & $\begin{array}{l}\text { Project } \\
\text { management plan } \\
\text { / participation in } \\
\text { the construction }\end{array}$ & $\begin{array}{l}\text { Community development } \\
\text { plan (basic services / } \\
\text { livelihood plan \& estate } \\
\text { management plan) }\end{array}$ \\
\hline $\begin{array}{l}\text { Manggahan } \\
\text { Floodway } \\
\text { (APOAMF) } \\
\text { under the } \\
\text { NHA in-city } \\
\text { resettlement } \\
\text { programme. }\end{array}$ & $\begin{array}{l}\text { Facilitated by the } \\
\text { APOAMF. The } \\
\text { group was in } \\
\text { charge of } \\
\text { selecting } \\
\text { beneficiaries of } \\
\text { the programme. } \\
\text { The NHA } \\
\text { approved the } \\
\text { presented list. }\end{array}$ & $\begin{array}{l}\text { Land } \\
\text { Identification } \\
\text { done by the } \\
\text { community } \\
\text { organisation } \\
\text { (CO). Initial } \\
\text { resistance of } \\
\text { NHA and the } \\
\text { necessity of } \\
\text { lobbying } \\
\text { politicians by } \\
\text { the CO to } \\
\text { secure land } \\
\text { access. The } \\
\text { initial offer of } \\
\text { the NHA to } \\
\text { resettle the } \\
\text { whole } \\
\text { community off- } \\
\text { site. }\end{array}$ & $\begin{array}{l}\text { Lack of real } \\
\text { influence. Initial } \\
\text { absence of CO from } \\
\text { the process of } \\
\text { selection. At a later } \\
\text { stage inclusion as an } \\
\text { observer. Three } \\
\text { subcontractors } \\
\text { employed in the } \\
\text { process. One failed to } \\
\text { deliver construction, } \\
\text { which was } \\
\text { suspended due to } \\
\text { conflict with the } \\
\text { workforce. }\end{array}$ & $\begin{array}{l}\text { CO pushing for } \\
\text { construction of } 49 \\
\text { buildings } \\
\text { accommodating all of } \\
\text { the APOAMF members. } \\
\text { Based on building law } \\
\text { and negotiations with } \\
\text { the NHA plans from } \\
\text { both sides were } \\
\text { merged. The number } \\
\text { decreased to } 15 \\
\text { buildings and } 867 \\
\text { units. Part of the } \\
\text { community opted for } \\
\text { off-site at Tanay due to } \\
\text { lower costs. CO } \\
\text { influenced the final } \\
\text { design of buildings } \\
\text { (door location, hallway } \\
\text { sites etc.). }\end{array}$ & $\begin{array}{l}\text {-Lack of influence } \\
\text { on management of } \\
\text { the construction } \\
\text { process. } \\
\text { - Due to low } \\
\text { remuneration only } \\
\text { ca. } 2 \% \text { of the } \\
\text { community was } \\
\text { employed in the } \\
\text { workforce } \\
\text { construction of the } \\
\text { estate. }\end{array}$ & $\begin{array}{l}\text { Preparation of management } \\
\text { guidelines in cooperation } \\
\text { with NHA and the CO. Four } \\
\text { committees were established: } \\
\text { community development, } \\
\text { livelihood, maintenance and } \\
\text { management. } \\
\text { After construction issues it } \\
\text { turned into a conflict filled } \\
\text { relationship: } \\
\text { in some of the buildings } \\
\text { people are informally in } \\
\text { charge of estate management } \\
\text { after declining to sign } \\
\text { contracts stipulating } \\
\text { employment of an external } \\
\text { condominium corporation. In } \\
\text { the other phase NHA takes } \\
\text { responsibility according to } \\
\text { their preferred regulations. }\end{array}$ \\
\hline $\begin{array}{l}\text { ALPAS Phase } \\
1 \text { under the } \\
\text { SHFC High } \\
\text { Density } \\
\text { Housing } \\
\text { programme }\end{array}$ & $\begin{array}{l}\text { Community } \\
\text { organised by the } \\
\text { People's } \\
\text { Organisation: } \\
\text { Kilos Maralita, } \\
\text { representatives } \\
\text { of different } \\
\text { barangays in } \\
\text { Caloocan } \\
\text { brought together } \\
\text { in order to form } \\
\text { several } \\
\text { homeowners } \\
\text { associations. }\end{array}$ & $\begin{array}{l}\text { Land research } \\
\text { done by the } \\
\text { CO. } \\
\text { Identification } \\
\text { of the land and } \\
\text { successful } \\
\text { negotiation } \\
\text { with the } \\
\text { private owner. } \\
\text { Near-city } \\
\text { relocation. }\end{array}$ & $\begin{array}{l}\text { CO approved a } \\
\text { developer suggested } \\
\text { by the } \\
\text { SHFC/mobiliser. }\end{array}$ & $\begin{array}{l}\text { Original design came } \\
\text { from the developer. } \\
\text { After beginning } \\
\text { construction of the first } \\
\text { buildings the } \mathrm{CO} \text { is } \\
\text { influencing the design } \\
\text { through enlarging the } \\
\text { unit size from } 21 \mathrm{~m}^{2} \text { to } \\
25 \mathrm{~m}^{2} \text { loft-like flats } \\
\text { (overall } 35 \mathrm{~m}^{2} \text { of floor } \\
\text { area) and the } \\
\text { introduction of } \\
\text { additional windows. }\end{array}$ & $\begin{array}{l}\text {-Systematic } \\
\text { monitoring of the } \\
\text { construction } \\
\text { process by the CO, } \\
\text { requesting } \\
\text { amendments and } \\
\text { use of correct } \\
\text { materials. } \\
\text {-Around } 50 \\
\text { members of CO } \\
\text { employed in the } \\
\text { construction } \\
\text { process. Number } \\
\text { reduced to ca. } 10 \\
\text { due to low wages. }\end{array}$ & $\begin{array}{l}\text { - In the process of } \\
\text { development by community } \\
\text { members and Kilos Maralita. } \\
\text { Designed seven committees } \\
\text { including maintenance, } \\
\text { ecology etc. } \\
\text {-Livelihood: planned } \\
\text { commercial rental spaces, } \\
\text { selling fertiliser from } \\
\text { recycled trash by } \\
\text { unprivileged members of the } \\
\text { community. }\end{array}$ \\
\hline
\end{tabular}

${ }^{4} \mathrm{~A}$ form of canal used as a part of drainage system in densely populated areas 
The ALPAS project began in 2012 when groups of informal settlers from different barangays in Caloocan and Metro Manila were approached by People's Organisation: the Kilos Maralita $(\mathrm{KM})$. The KM helped to organise the leadership of the communities involved. From the start the intention was to embark on a project using the People's Plans. The process commenced with a land search which resulted in the identification of a private parcel directly outside Metro Manila, in the city of San Jose Del Monte. The 'near city' location was acceptable to the network of communities due to its proximity to their original informal settlements in Caloocan. Negotiations led to the signing of an 'intent to sell' letter with the owner of the land. In the meantime the informal settlers had to organise homeowners associations (HOA) to fit within the loan regulations and source support through the High Density Housing programme. The project benchmark was set at 546 units. Approximately 50 Informal Settler Families refused to join the process. According to the HOA's leadership this was linked to a lack of faith in the success of the project. After obtaining the loan, the HOA selected a developer suggested by the finance agency administering the loan and approved the neighbourhood and housing design. Only after construction of the first buildings had begun did the HOA leadership demand changes in the size of flats in the remaining buildings.

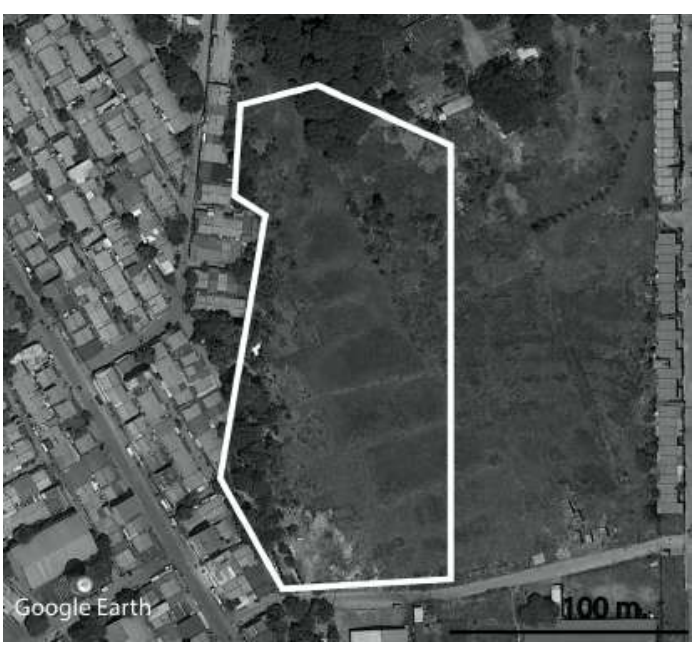

Figure 6. Project site in February 2015. Source: Google Earth

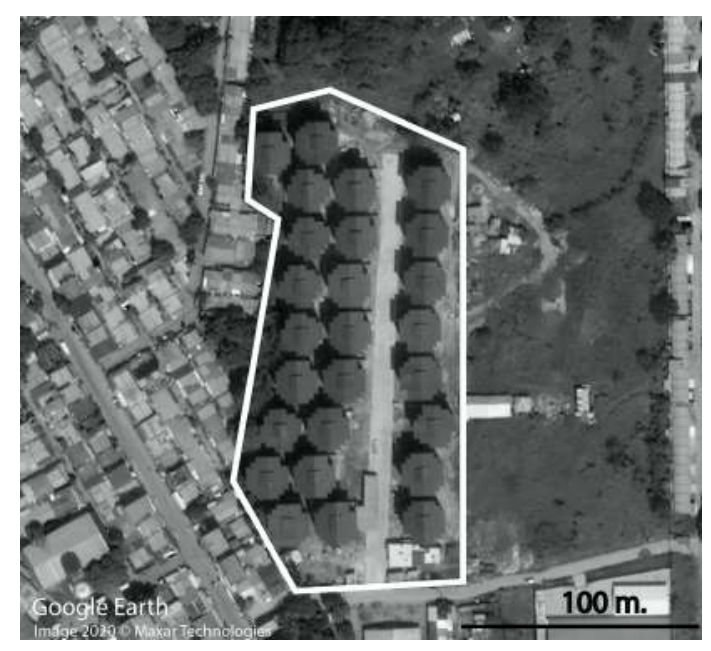

Figure 7. Project site in November 2018, Source: Google Earth 


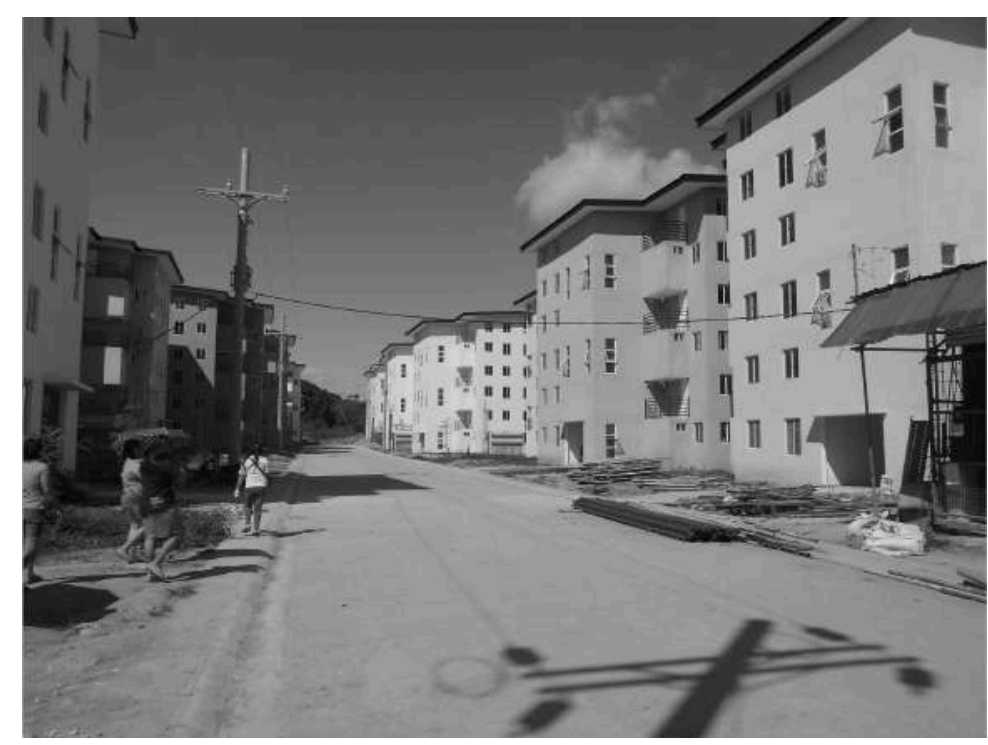

Figure 8. Multi-storey housing developed within ALPAS project, source: author

The HOAs engaged in rigorous monitoring of the building progress and intervened with the developer on several occasions. Some of its members were employed as construction workers, although the majority resigned because of low wages. By February 2018 the families were ready to sign certificates of occupancy, pending approval of the local Fire Department concerning safety regulations, which followed a set of other administrative regulations the groups had to comply with. Although no water or electricity connections were secured at this time a small number of families moved on to the site, fearing that the buildings might be occupied by external groups. The HOA formed seven committees to manage the buildings. Overall, the envisaged solutions for the estate included livelihood creation and economic management such as turning the community's waste into fertiliser and the installation of solar panels to provide $40 \%$ of the estate's electricity requirement. Additionally, some spaces were reserved as rental spaces for economic activities such as shops or stalls and linked to the network of commercial spaces to be managed by Kilos Maralita, through a system encompassing housing estates in Metro Manila whose construction they supported.

\section{Commonalities and differences}

The case studies illustrate that People's Plans helped to facilitate communities' engagement in the development of multi-storey housing and its specific components benefited from the solutions originating from the informal sector. However, the extent to which this was 
achieved varied depending of the type of undertaken activity. The strongest input on communities' side happened within community organisation, profiling and search for the land. In both cases community leaders created a list of people capable to engage in the process and found the land fitting to their needs. However, in the case of APOAMF, the informal negotiations and the securing of support from politicians were crucial for the realisation of the project due to the central location of the selected plot. This difference points to the fact that in locations where land prices are high the key power holders may be prone to opposing community-driven multi-storey housing due to the potential financial return from the land in question. For communities this will mean that institutionalised mechanisms of land access will not suffice to purchase their desired lot. Rather, the process may require engagement in off-the-scene lobbying or resorting to protest or contestation. Similarly, in the cases reviewed, as well as in a couple of other projects, attempts by communities to purchase land from the public sector proved to be harder than negotiating with individual owners. However, such negotiations are also unlikely to be successful in locations where land values grow rapidly.

The level of input into the management of site construction, financial process and development of community-led property management system as well as livelihood plan was relatively high but varied in both cases. The public sector-community cooperation went relatively smoothly in the ALPAS project, where the leadership was in charge of the internal management of fees collection for the loan repayment, supervision over the construction process and development of maintenance and livelihood system. In the APAOMF project the community leadership had limited impact on the supervision over the works and struggled to establish property maintenance system for the whole site. Due to a conflictual relationship with public sector, there are currently two parallel property management systems running in specific buildings on the site, one led by the community and the other by the National Housing Authority.

In both cases input into the design of site and housing was possible. On one hand, some adaptations happened in both projects during design and construction phase. Additionally, individual adaptations were possible, for instance in the context of the ALPAS project where mezzanine areas could be added directly by inhabitants in each of the flats. Overall, the community leadership reported satisfaction of the members of their groups concerning the quality of the housing, particularly in terms of their resilience to natural disaster risks. On the other hand, strict building codes limited the adaptability of the design of sites and buildings. For instance, the whole APOAMF project was scaled down due to limits 
to the number of houses that could be built on the site. This led many families, particularly those with lower incomes, to move to a distant relocation site.

The last component of the process, the engagement of people directly in the construction, illustrates the difficulty of breaking the formal and informal binary within multi-storey housing form as most the expertise remains with the developer who needs to maximise timely outputs and minimise the costs of the work. Even from the perspective of civil society, 'to ensure quality homes, the organisation or the person who really has the expertise on construction should be given the role of (...) managing the construction' (civil society, 24-11-2017). At the same time and similarly to the incremental housing projects, the solution was supposed to result in the engagement of community members into the construction of buildings, since 'the workers are still from the community' (civil society, 2411-2017). However, this assumption was not truly realised in either of the two projects because remuneration and working conditions were unattractive for the community members. Those who were employed quickly resigned, leaving the rest of the works to be continued by external contracted workers.

What the cases illustrate is that crossing the formal-informal binary is facilitated by the co-productive process even in the case of multi-storey housing, which is typically associated with a rigid, top-down process and mass housing delivery systems. Three key factors were crucial for the realisation of the discussed projects. Firstly, the land access question, which differed in both cases, illustrated how the issue of location may affect the housing process. Secondly, the approach of the public sector towards the People's Plan mattered greatly. Even in a context in which the public sector was contesting the elements of the approach, co-production helped facilitate the process and steer negotiations between the different groups. However, an unfavourable response from the public sector also results in massive delays, forces communities to focus on lobbying politicians and may limit the extent to which the people's preferences are integrated. Thirdly, the mobilisation of the leadership of community groups involved, the forming of connections with external community networks or dedicated mobilisers, can play a crucial role in the housing process. In the absence of this, many communities (or parts of communities) under pressure of relocation and with an offer of a ready-made housing product in a distant relocation site, will agree to be resettled instead of engaging in a long and complex co-productive mechanism (Galuszka, 2019b). 


\section{Discussion and conclusions}

The People's Plan approach was developed in Metro Manila and applied within the Oplan LIKAS programme as an unconventional solution, which merged experiences from in-situ upgrading schemes within a built form conventionally fitting the imaginaries of a formal city. It achieved this by employing a co-productive process in a resettlement setting.

Overall, while the approach offers an opportunity for communities to access housing in desired locations, provide input on design and control various aspects of the delivery process, it is not free from vulnerabilities. The acceptance for incorporating informal processes is guaranteed mainly thanks to massive lobbying of civil society and is mostly visible within the project phases which are considered by public sector as not requiring high professional skills (like community profiling or land research). Simultaneously, the communities which are willing to engage into the process still need to comply with a tedious administrative process operating with a complex legal and technocratic language. Additionally, apart from purely practical issues such as the affordability of in-city housing for part of informal dwellers (COA, 2017), the complexity of the process (Ballesteros, 2017) or opportunistic corruption inflicted by the public sector, the approach is also challenged on a governance and organisational level. This contestation by the public sector remains crucial for understanding the process involved in creating a formal-informal binary in contemporary cities. Even in an initially favourable context, such as Oplan LIKAS, where civil society had the tools to influence the way the programme was set up, some involved shelter agencies and local government units contested the approach. On a broader scale, opposition to the people's solutions is illustrated by the fact that majority of the programme's budget was spent on conventional low-rise, off-city resettlement sites delivered by big developers, which in the end meant skewing the principles of people's instigated governance shift (Galuszka, 2019b). Similar contestation also occurred at project level and within the implementation of People's Plans. For example, the community profiling was criticised by the NHA as being nontransparent: "we are much better than SHFC (Social Housing Finance Corporation) in terms of output, in terms of the qualification of the beneficiaries, we heard that even non-qualified beneficiaries are given the allocation. That's our allegation but in the case of NHA we ensure that only qualified families who were not given housing assistance before are provided with housing assistance' (public sector, 01.02.2019). This assumption, which may be accurate in specific contexts, reveals the public sector's inherent belief that messiness within the informal process is bound to create a malfunctioning system. However, it fails to acknowledge that 
corruption, lack of transparency and arbitrariness is also a part of more rigid, technocratic approaches. In a similar fashion the community-based land searches were viewed unfavourably by the public sector (as in APOAMF case) and cases were reported of land identified by communities being hastily purchased by Local Government Units, in effect exploiting the search work done by the urban poor for their own purposes and programmes. Conversely, civil society members share distrust in technocratic solutions, while bottom-up approaches may themselves incorporate non-transparent mechanisms dependant on community leaders or consultants involved in the process.

Additionally the process opens an extremely relevant pathway for direct cooperation between civil society and the private sector - a pathway that potentially challenges one of the strongest assumptions of the 'formal city', namely that it is the public sector in cooperation with private sector that draws up contracts and decides who will earn money. The multistorey housing approach shows that there is scope for socially-oriented developers ${ }^{5}$ and the informal sector to work together, thus enabling the urban poor to impact the process which is typically owned by professionals and the public sector. This challenges not only the city imaginaries but also the conventional pathway of employing large-scale contractors who, within the currently dominant, neo-liberal paradigm of a city, deliver peripheral, mass-social housing.

This resistance by the public sector is not surprising, neither as regards their beliefs (as in the community profiling aspect) nor as regards their interests and exercise of power (as in the land search and contracting question). The case studies illustrate the complexities of these relations. The ALPAS project was realised in a context where competition for land was not extremely high. The process was relatively smooth and resulted in the creation of an extensive housing site, with adapted design, possibility of adding loft area in flats and emerging communal facilities. For the APOAMF the co-productive process was in fact a strong negotiation tool in a relationship with a public sector characterised by an ambiguous conflict-cooperation dynamic, where each of the sites struggled over the control of the process. The project suffered multiple complications yet is still considered an example of the success of the urban poor in making their People's Plan, a point of view not shared by the public sector. In this context, and in a broader scale, this example illustrates the paradoxical positioning of the People's Plan. On one hand, the approach was criticised by Local

\footnotetext{
${ }^{5}$ Beyond the presented studies this was also documented within AMVACA project in Valenzuela City or the Ernestville HOA in Quezon City - see Ballesteros et al. 2017.
} 
Government Units as too slow, and conflicting with their mandate to vacate waterways in Metro Manila as rapidly as possible. On the other hand, it facilitated some conflict-free resettlement to off-city sites (Alvarez, 2019) by giving 'an option' for the members of the community to stay nearby their original settlement. As much as part of the local community used this opportunity, the public sector downscaled the original size of the project by resorting to existing building codes and 'formal' logic of development, a mechanism which resonates with the notion of conflicting rationalities in urban development (Watson, 2003). Efforts to overcome the divide are necessary for any people's solutions to be mainstreamed. Co-production remains an important tool for the urban poor sector to navigate this kind of unfavourable governance context, but the reflection on its impact on a broader governance structures remains crucial.

One such outcome can be documented in terms of the People's Plan approach. Despite being plagued by practical issues, the people's process for the development of multistorey housing in Metro Manila shows that the informal sector is capable of completing a project outside a 'slums' or shacks context. This is extremely important. The ability of community groups to navigate such a complex and unexpected context as multi-storey housing development pushes the boundaries of what can be done 'for them' but 'without them'. When public officials, as well as housing markets, increasingly turn their attention to low-income multi-storey housing delivery systems, experiences such as those of the People's Plan can be used to counterbalance the replication of top-down housing models and open up a discussion about incrementality, adaptable design, and mixed-use spaces in multi-storey housing. Perhaps the aspect of challenging the informal-formal dichotomy can in this context be discussed as part of a broader transformation process towards more equitable and just cities. While there are obvious limits to what the discussed co-productive process can do, such as unblocking sufficient amount of land in the most valuable areas of metropolises, it holds the potential for changing the rules of the game in the conventionally 'formal' housing development process.

When juxtaposed with the dominant understanding of housing co-production in the South (involving such mantras as enumeration, showing by doing, incremental upgrading) this remains a crucial piece of data both for the urban poor and for the civil society sector. Challenges to what formal and informal actually mean can happen within the most unexpected of contexts and can upset even powerful imaginaries of urban morphology. 


\section{Acknowledgments:}

I would like to thank community members from ALPAS and APOAMF as well as representatives of NGOs and public sector who helped to facilitate this study, including: Kreeger Bonagua, Tess Siat, Eric Villanueva, Ricky Gonzales. I am also grateful to PIDS and dr. Marife Ballesteros for supporting the study and participation in the site visit in Pasig as well as to the anonymous reviewers for valuable feedback.

\section{References}

Acuto, M., Dinardi, C. and Marx, C. (2019) 'Transcending (in) formal urbanism'. Urban Studies, 56(3), 475-487.

Agus, M. R. (2002) 'The role of state and market in the Malaysian housing sector'. Journal of Housing and the Built Environment, 17(1), 49-67.

Albrechts, L. (2012) 'Reframing strategic spatial planning by using a coproduction perspective', Planning theory, 12(1), 46-63.

Alvarez, M.K. (2019) 'Benevolent evictions and cooperative housing models in post-Ondoy Manila', Radical Housing Journal, 1(1), 49-68.

Arku, G. (2006) 'The housing and economic development debate revisited: economic significance of housing in developing countries', Journal of Housing and the Built Environment, 21(4), 377-395.

Asia Foundation (unknown) 'People's Plan Primer - an Action Guide to People's Shelter Planning'.

Ballesteros, M. M. (2002) 'Rethinking institutional reforms in the Philippine housing sector', PIDS Discussion Paper Series, 2002-16, 1-52.

Ballesteros, M. M., Ramos, T. P. and Magtibay, J. E. (2017) 'An Assessment of the Community Mortgage Program Implementation Strategy', PIDS Research Paper Series, 2017-1, 1-83.

Barenstein, J. D., and Pfister, M. (2019) 'The Professionalization of a Social Movement: Housing Cooperatives in Uruguay', Built Environment, 45(3), 382-397.

Beall, J. (2001) Valuing social resources or capitalizing on them? Limits to pro-poor urban governance in nine cities of the south. International Planning Studies, 6(4), 357-375.

Boonyabancha, S. and Kerr, T. (2018) 'Lessons from CODI on co-production', Environment and Urbanization, 30(2), 444-460. 
Bredenoord, J., Van Lindert, P. and Smets, P. (eds) (2014) Affordable housing in the urban global south: seeking sustainable solutions. Routledge

Bovaird, T. (2007) 'Beyond engagement and participation: User and community coproduction of public services', Public administration review, 67(5), 846-860.

Bradlow, B. H. (2015) 'City learning from below: urban poor federations and knowledge generation through transnational, horizontal exchange', International Development Planning Review, 37(2), 129-142.

Brown-Luthango, M. (2016) 'Collective (in) efficacy, substance abuse and violence in "Freedom Park," Cape Town', Journal of Housing and the Built Environment, 31(1), 123140.

Buckley, R.M., Kallergis, A. and Wainer, L. (2016) 'Addressing the housing challenge: avoiding the Ozymandias syndrome', Environment and Urbanization, 28(1), 119-138.

Burgess R (1978) 'Petty commodity housing or dweller control? A critique of John Turner's views on housing policy', World Development 6(9), 1105-1133.

Commission of Audit (2017) Performance Audit Report. In City Resettlement Housing Programme. https://www.coa.gov.ph/phocadownloadpap/userupload/performance-auditreport/2017/PAO-2017-02_Housing_Program.pdf (accessed 12.12.2018)

Dovey, K. (2012) 'Informal urbanism and complex adaptive assemblage', International Development Planning Review, 34(4), 349-368.

Galuszka, J. (2014) 'Community-based approaches to settlement upgrading as manifested through the big ACCA projects in Metro Manila, Philippines', Environment and Urbanization, 26(1), 276-296.

Galuszka, J. (2019a) 'What makes urban governance co-productive? Contradictions in the current debate on co-production', Planning Theory, 18(1), 143-160.

Galuszka, J. (2019b) 'Co-Production as a Driver of Urban Governance Transformation? The Case of the Oplan LIKAS Programme in Metro Manila, Philippines', Planning Theory \& Practice, 395-419

Garrido, M. (2013) 'The ideology of the dual city: The modernist ethic in the corporate development of Makati City, Metro Manila', International Journal of Urban and Regional Research, 37(1), 165-185.

Giles, C. (2003) 'The autonomy of Thai housing policy, 1945-1996', Habitat International, $27(2), 227-244$.

Greene, M. and Rojas, E. (2008) 'Incremental construction: a strategy to facilitate access to housing', Environment and Urbanization, 20(1), 89-108. 
Arif Hasan and Associates, Architects and Planning Consultants (1990) 'Evaluation of HDA's Khuda Ki Basti Incremental Housing Scheme'.http://arifhasan.org/wpcontent/uploads/2012/09/AH18_HADs-KKB-scheme.pdf (accessed 20 March 2019)

Hasan, A., Sadiq, A. and Ahmed, S. (2010) 'Planning for high density in low-income settlements: four case studies from Karachi', Human Settlements Group, International Institute for Environment and Development.

Huchzermeyer, M. and Misselwitz, P. (2016) 'Coproducing inclusive cities? Addressing knowledge gaps and conflicting rationalities between self-provisioned housing and state-led housing programmes', Current Opinion in Environmental Sustainability, 20, 73-79.

Joshi, A. and Moore M. (2004) 'Institutionalised coproduction: unorthodox public service delivery in challenging environments', Journal of Development Studies, 40(4), 31-49.

Joshi, S. and Khan, M. S. (2010) 'Aided self-help: the million houses programme-revisiting the issues', Habitat International, 34(3), 306-314.

Karaos, A.M. (2006) 'Populist mobilization and Manila's urban poor: the case of SANAPA in the NGC East Side', in A. Fabros, J. Rocamora and D. Velasco (eds), Social movements: experiences from the Philippines. Quezon City: Institute for Popular Democracy, 46-102 Karaos, A.M., Nicolas, G. and Rabacal, G.A. (2011) 'Innovative urban tenure in the Philippines. Challenges, approaches and institutionalization'. Nairobi, UN- Habitat.

Karaos, A.M. and Porio, E. (2015) 'Transforming the housing process in the Philippines: The role of local-global networks by the urban poor' in P. Herrle, A. Ley \& J. Fokdal (eds), From local action to global networks: Housing the urban poor, London, Ashgate Publications, 107121.

Lemanski C (2017) 'Unequal citizenship in unequal cities: Participatory urban governance in contemporary South Africa', International Development Planning Review 39(1), 15-35.

Lin, Y. (2018) 'An institutional and governance approach to understand large-scale social housing construction in China', Habitat International, 78, 96-105.

Informal Settler Families - National Technical Working Group (ISF-NTWG) (2014) Operational Guidelines in the Transfer of Informal Settler Families from Danger Areas in the National Capital Region.

McFarlane C. (2012a) 'Rethinking Informality: Politics, Crisis, and the City', Planning Theory \& Practice, Vol. 13, No. 1, 89-108.

McFarlane, C. (2012b) 'The Entrepreneurial Slum: Civil Society, Mobility and the Co- 
production of Urban Development', Urban Studies, 49(13) 2795-2816.

McFarlane, C. and Waibel, M. (2012) 'Introduction: The informal-formal divide in context' in C. McFarlane and M. Waibel (eds), Urban informalities, Franham, Ashgate, 1-12.

Mitlin, D (2008) 'With and beyond the state: coproduction as a route to political influence, power and transformation for grassroot organizations', Environment and Urbanization, 20(2), $339-360$.

Mitlin, D. (2018) 'Beyond contention: urban social movements and their multiple approaches to secure transformation', Environment and Urbanization, 30(2), 557-574.

Mitlin, D., and Bartlett, S. (2018) 'Co-production-Key ideas', Environment and Urbanization, 30(2), 355-366.

Morley, I. (2018) 'Manila', Cities, 72, 17-33.

Ostrom, E. (1996) 'Crossing the great divide: coproduction, synergy, and development', World development, 24(6), 1073-1087.

Patel, S., Baptist, C. and d'Cruz, C. (2012) 'Knowledge is power-informal communities assert their right to the city through SDI and community-led enumerations', Environment and Urbanization, 24(1), 13-26.

Patiño, P.I. (2016) 'Building resilient and safe communities against poverty and disaster'. Asian Cities Climate Resilience, Working Paper Series 29, International Institute for Environment and Development.

Payne, G., Durand-Lasserve, A. and Rakodi, C. (2009) 'The limits of land titling and home ownership, Environment and Urbanization, 21(2), 443-462.

Porio, E. (2012) 'Decentralisation, power and networked governance practices in Metro Manila', Space and Polity, 16(1), 7-27.

Presidential Decree no 757 (1975)

https://www.lawphil.net/statutes/presdecs/pd1975/pd 757 1975.html (accessed 20

November 2018)

Pieterse, D. E. (2013) City futures: Confronting the crisis of urban development. New York, Zed Books Ltd..

Roy, A. and AlSayyad, N. (eds) (2004) Urban Informality: Transnational Perspectives from the Middle East, Latin America and South Asia. Lanham, MD, Lexington Books.

Roy, A. (2009) 'Civic governmentality: The politics of inclusion in Beirut and Mumbai', Antipode, 41(1), 159-179. 
Shand, W. (2018) 'Making spaces for co-production: collaborative action for settlement upgrading in Harare, Zimbabwe', Environment and Urbanization, 30(2), 519-536.

Shatkin, G. (2002) 'Working with the community: Dilemmas in radical planning in Metro Manila, the Philippines', Planning Theory \& Practice, 3(3), 301-317.

Shatkin, G. (2004) 'Planning to forget: Informal settlements as' forgotten places' in globalising Metro Manila', Urban Studies, 41(12), 2469-2484.

Shatkin, G. (2016) Collective action and urban poverty alleviation: Community organizations and the struggle for shelter in Manila. London, Routledge.

Silas, J. (1992) 'Government-community partnerships in Kampung Improvement Programmes in Surabaya' Environment and Urbanization, 4(2), 33-41.

Song, L. K. (2016) 'Planning with urban informality: a case for inclusion, co-production and reiteration', International Development Planning Review, 38(4), 359-381.

Turner, J.F. and Fichter, R. (eds) 1972 Freedom to Build: Dweller Control of the Housing Process, Macmillan.

Turok, I. (2016) 'Housing and the Urban Premium', Habitat International, 54, 234-40.

Warouw, F., Kobayashi, H. and Jung, J. (2010) 'A Study on the Open Building System for Multi-Storey Housing in Indonesia', Journal of Asian Architecture and Building Engineering, 9(2), 339-346.

Watson, V. (2003) 'Conflicting Rationalities: Implications for Planning Theory and Ethics', Planning Theory \& Practice, 4(4), 395-407.

Watson, V. (2014) 'Co-production and Collaboration in Planning - the Difference', Planning Theory \& Practice, 15(1), 62-76.

World Bank (2016) 'Republic of the Philippines Housing and Urban Development Summit. Closing the Gap in Affordable Housing in the Philippines: Policy Paper for the National Summit on Housing and Urban Development', Manila, World Bank

World Bank (2017) 'Philippines urbanization review: Fostering competitive, sustainable, and inclusive cities', Washington, D.C, World Bank.

Yap, K. S. (2016) 'The enabling strategy and its discontent: Low-income housing policies and practices in Asia', Habitat International, 54, 166-172

Yap, K. S. and De Wandeler, K. (2010) 'Self-help housing in Bangkok', Habitat International, 34(3), 332-341. 
$\mathrm{Yu}$, S. and Karaos, A. M. (2004) 'Establishing the role of communities in governance: the experience of the Homeless People's Federation Philippines', Environment and Urbanization, 16(1), 107-120. 